\title{
HLA Genes in Populations of the Aleutian Islands
}

\author{
DIEGO REY, ' CRISTINA ARECES, ' CARLOS PARGA-LOZANO, PABLO GÓMEZ-PRIETO, ' \\ MICHAEL H. CRAWFORD, ${ }^{2}$ AND ANTONIO ARNAIZ-VILLENA'
}

\begin{abstract}
We typed a subset of the Aleut population for HLA loci (HLA-A, $H L A-B, H L A-D R B 1, H L A-D Q B 1)$ to obtain an HLA profile, which was compared to other Eurasian and Amerindian populations for studying Aleut origin and its significance on the peopling of the Americas. Allele frequencies at the four loci were identified in an Aleut sample using standard indirect DNA sequencing methods. Genetic distances with Amerindians and Eurasians were obtained by comparing Aleut allele frequencies with a worldwide population database (13,164 chromosomes). The most frequently extended HLA haplotypes were also calculated. We also generated Aleut relatedness dendrograms and calculated correspondence relatedness in a multidimensional scale. Both neighbor-joining dendrograms and correspondence analysis separated Aleuts from Eskimos and Amerindians. Aleuts are closer genetically to Europeans, including Scandinavians and English. Our results are concordant with those obtained by Y-chromosome analysis, suggesting that most male Aleut ancestors of our sample came mainly from Europe.
\end{abstract}

Aleuts are closely linked to the Eskimos with regard to the peopling of the Americas, but according to cultural and anthropological parameters, they have a distinct culture and a different origin and time of arrival in the Americas. The eastern Aleuts call themselves Unangan and the western Natives of the archipelago were called Aleuts by Russians ("Aleut" comes from Allíthuh; http://www.eki. ee/books/redbook/aleuts.shtml). Contemporary Aleuts have a relatively homogeneous common culture with two linguistic dialects that are mutually intelligible (Zlojutro et al. 2006). Genetic studies from mummies dated to $657 \mathrm{BC}$ and Aleut remains dated to $\mathrm{AD} 1403$ suggest a genetic continuity with present-day Aleut people (Zlojutro et al. 2006). In addition, the genetic structure of the populations of the Aleutian archipelago approximate an isolation-by-distance kin migration model (Crawford 2007). Mitochondrial DNA has been analyzed in Aleuts and compared to other populations. These analyses have shown more mtDNA affinities with Asian Chukchi and Siberian Eskimos than with Amerindians or U.S. Eskimos (Rubicz et al. 2003; Zlojutro et al. 2006). Interestingly, despite apparent

\footnotetext{
'Department of Immunology, Madrid Regional Blood Center, Facultad de Medicina, Universidad Complutense de Madrid, Avenida Complutense s/n, 28040 Madrid, Spain.

${ }^{2}$ Department of Anthropology, University of Kansas, Lawrence, KS 66045.
}

Human Biology, October-December 2010, v. 82, nos. 5-6, pp. 737-744.

Copyright $($ C 2010 Wayne State University Press, Detroit, Michigan 48201-1309

KEY WORDS: ALEUTS, AMERINDIANS, EUROPEANS, FINNS, HLA. 
Aleut admixture with Eurasians, the mtDNA data show little evidence of European admixture. However, recently, Zlojutro et al. (2009) showed that about $85 \%$ of $\mathrm{Y}$ chromosomes analyzed in Aleut populations are of Russian, Scandinavian, and Western European origin.

The aim of the present study is to generate an Aleut HLA profile (autosomal) and compare it with profiles of worldwide populations. This comparison would complement the nonautosomal Y-chromosome and mtDNA studies for tracing Aleut origin. In addition, the characterization of the Aleut HLA profile may be useful for future Aleut transplantation programs and HLA epidemiology. A total of 13,164 worldwide European, Asian, Native American, and African chromosomes were used for the comparisons (Moscoso et al. 2008).

\section{Materials and Methods}

Following institutional review board approval, permission from the Aleutian Corporation, the Aleut/Pribilof Island Association, and Island Tribal Councils, and individual informed consent, a joint Russian-U.S. research team collected blood samples from Bering Island. Eighty-five unrelated Aleut individuals were used for the present study to type the HLA-A,HLA-B,HLA-C, HLA-DRB1, and $H L A-D Q B 1$ genes. Thirty-six of the volunteers had two Aleut parents; 49 individuals had one Aleut parent. We analyzed 121 Aleut HLA haplotypes. Aleuts had been relocated by the Russian colonial administration from Attu and Atka islands to Bering Island between 1825 and 1828 (Rubicz et al. 2003).

HLA typing was performed using a standard Luminex high-resolution typing for the five $H L A$ alleles, as described by Moscoso et al. (2008). Statistical analyses were performed using Arlequin (for the construction of extended HLA haplotypes), DISPAN (relatedness dendrograms), and VISTA (correspondence analysis) (Moscoso et al. 2008). Aleut HLA frequencies were compared with 13,164 chromosomes from a worldwide sample of populations [see Moscoso et al. (2008, Table 1) for population references].

\section{Results}

A single $H L A-D R B 1$ study was preferred to compare the Aleut HLA population frequencies with those of Europeans and Siberians who lacked $H L A-D Q B 1$ analyses. Figure 1 depicts an $H L A-D R B 1$ neighbor-joining tree and shows how the Aleuts cluster together with Scandinavian and Siberian populations and are separate from the Na-Dene and Eskimo Native American groups and also from the Asian and Mediterranean populations. Correspondence analyses based on variances of the mean genetic distances were carried out, and they revealed that Aleuts grouped together with European (Scandinavian and European) and some Siberian populations but also remained separated from the Amerindian, Na-Dene, and Eskimo Native American groups and from the Asian populations (Figure 2). 


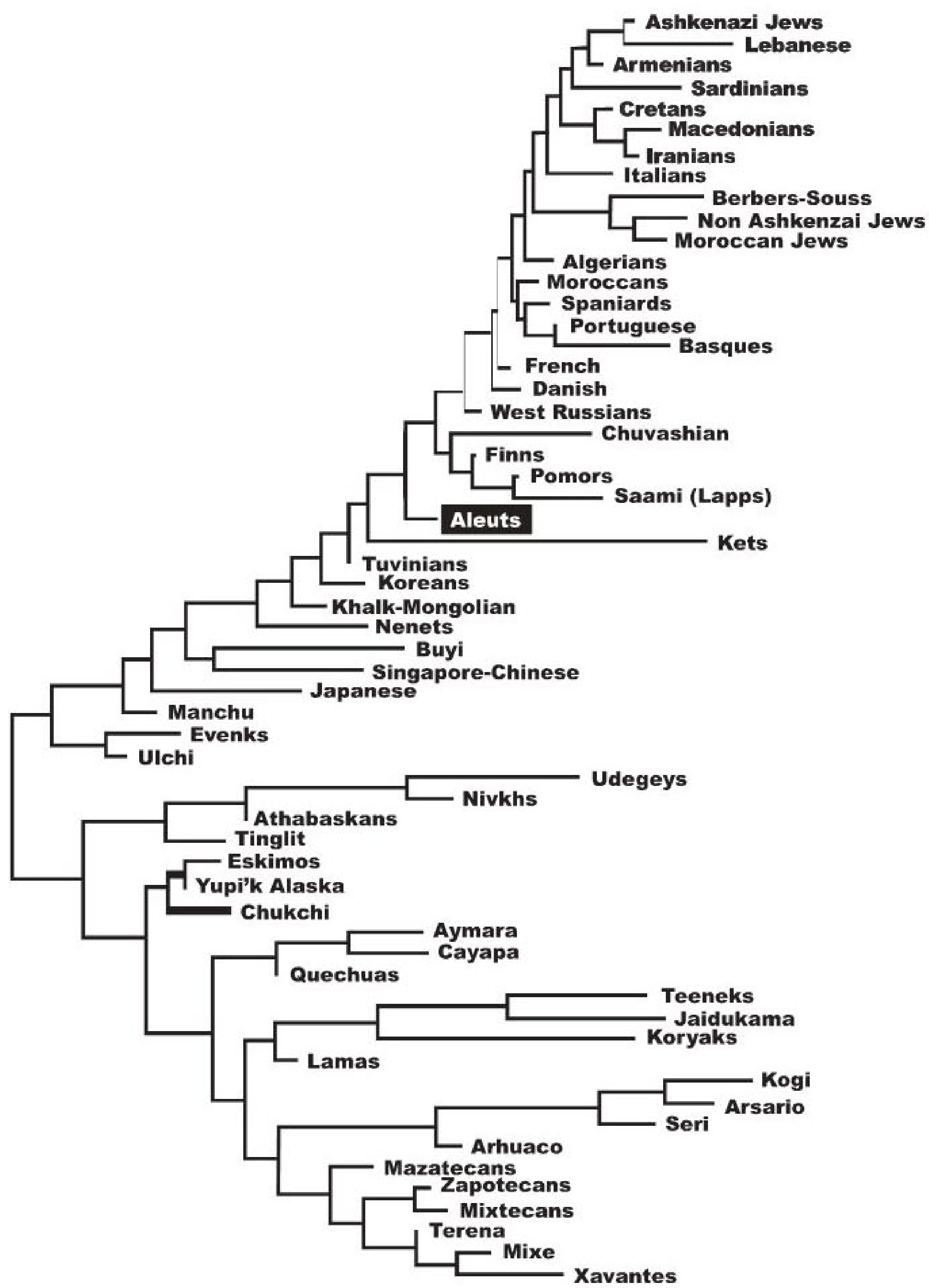

Figure 1. Neighbor-joining dendrogram showing relatedness between Aleuts and Amerindians, NaDene and Eskimo, and Asian and European populations. Genetic distances between populations $\left(D_{A}\right)$ were calculated using $H L A-D R B I$ genotyping. Data from other populations were taken from Moscoso et al. (2008, Table 1). 
740 / REY ET AL.

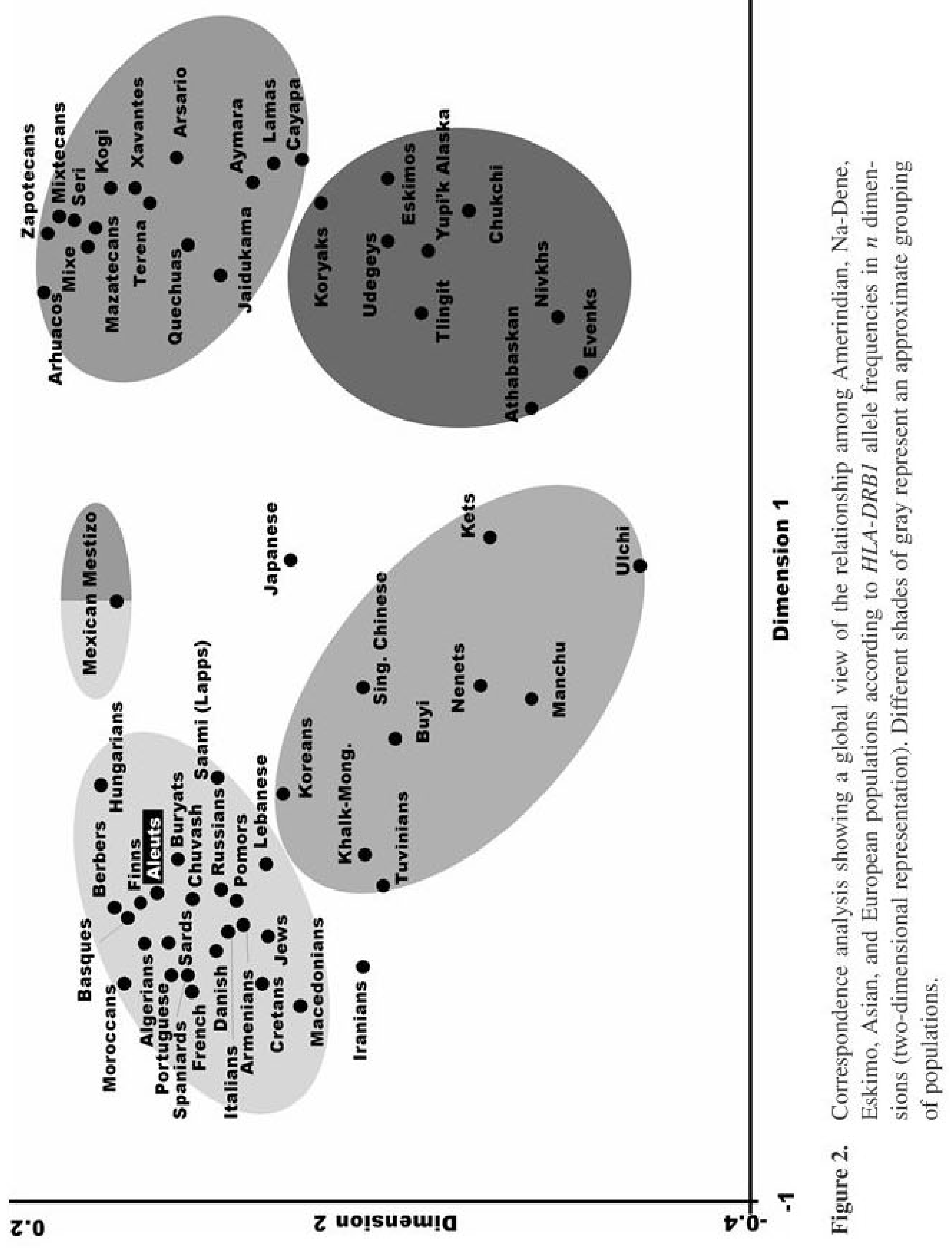


Table 1. Ten Most Frequent HLA-A, HLA-B, HLA-C, HLA-DRBI, and HLA-DQBI Extended Haplotypes

\begin{tabular}{lcl} 
Haplotype & Haplotype Frequency $(\%)$ & Possible Origin \\
\hline$A^{*} 0301-C^{*} 0401-B^{*} 3503-D R^{*} 0801-D Q^{*} 0402^{\mathrm{a}}$ & 8.3 & East European \\
$A^{*} 2402-C^{*} 0304-B^{*} 4002-D R^{*} 1401-D Q^{*} 0503^{\mathrm{b}}$ & 6.9 & Asia, Alaska Yupik \\
$A^{*} 2402-C^{*} 0803-B^{*} 4801-D R^{*} 0401-D Q^{*} 0301^{\mathrm{c}}$ & 6.9 & Alaska Yupik \\
$A^{*} 0101-C^{*} 0701-B^{*} 0801-D R^{*} 0701-D Q^{*} 02^{4}$ & 5.6 & East European \\
$A^{*} 0201-C^{*} 0304-B^{*} 4001-D R^{*} 0101-D Q^{*} 0501^{\mathrm{e}}$ & 5.6 & Aleuts \\
$A^{*} 2402-C^{*} 0602-B^{*} 3701-D R^{*} 0801-D Q^{*} 0402^{\mathrm{c}}$ & 4.2 & Aleuts \\
$A^{*} 2402-C^{*} 0702-B^{*} 3901-D R^{*} 0404-D Q^{*} 0302^{\circ}$ & 4.2 & Aleuts \\
$A^{*} 2402-C^{*} 1203-B^{*} 3901-D R^{*} 1201-D Q^{*} 0301^{\mathrm{e}}$ & 4.2 & Aleuts \\
$A^{*} 0201-C^{*} 0303-B^{*} 1501-D R^{*} 0401-D Q^{*} 0301^{\mathrm{e}}$ & 2.8 & Aleuts \\
$A^{*} 0201-C^{*} 0701-B^{*} 5101-D R^{*} 1501-D Q^{*} 0602^{\mathrm{e}}$ & 2.8 & Aleuts \\
\hline
\end{tabular}

a. Found in Germans (1.6\%).

b. Found in Yupik Alaska Natives (5.4\%), Taiwan (6\%), Inuit, and Japanese.

c. Found in Yupik Alaska Natives (4.3\%).

d. Found in Germans (1.8\%) and Basques from Arratia (2.6\%).

e. Not found in any other population.

Two-dimensional plots of $D_{A}$ genetic distances between Aleuts and other populations demonstrate that Aleuts are both closer to Europeans and Scandinavians and to Asian (Siberian and Central Asian) populations than to Amerindians and Eskimos. Indeed, Finns, west Russians, Tuvinians, Pomors (or Arkangelks, northwest Russia), Portuguese, Koreans, Danish, French, Algerians, and Spaniards show the closest genetic distances to Aleuts, followed by Moroccans, Moroccan Jews, and Saami (or Lapps, northwest Russia). It is worth pointing out that Amerindian, Na-Dene, and Eskimo populations are ethnic groups that are genetically distant to Aleuts in the analysis.

The most frequent extended haplotypes found in the Aleut population are $D R B 1 * 0801-D Q B 1 * 0402$ in association with $A * 0301-C * 0401-B * 3503$ and $A * 2402-C * 0602-B * 3701$ (12.5\% of total haplotypes). The first of these extended haplotypes has been found previously only among Germans, and the second extended HLA haplotype has not been found in any other worldwide population, except in Aleuts (Table 1). The DRB1*0401-DQB1*0301 class II haplotype is present in two of the most frequent haplotypes in association with $A * 2402-C * 0803$ $B * 4801$ and $A * 0201-C * 0303-B * 1501$ (Table 1). These haplotypes are observed in $9.7 \%$ of the population. Other class II haplotypes (some not shown because they are present at extremely low frequencies), such as $D R B 1 * 1401-D Q B 1 * 0503$ (in association with $A * 2402-C * 0304-B * 4002$ ), $D R B 1 * 0701-D Q B 1 * 02$ (in association with $A * 0101-C * 0701-B * 0801$ ), DRB1*0101-DQB1*0501 (in association with $A * 0201-C * 0304-B * 4001$ ), DRB1*0404-DQB1*0302 (in association with $A * 2402-C * 0702-B * 3901$ ), $D R B 1 * 1201-D Q B 1 * 0301$ (in association with $A * 2402-C * 1203-B * 3901$ ), and $D R B 1 * 1501-D Q B 1 * 0602$ (in association with 
$A * 0201-C^{*} 0701-B^{*} 5101$ ), add up to $29.3 \%$ of all observed haplotypes. The 10 most common haplotypes account for $51.5 \%$ of the total haplotypes, and only $27.7 \%$ of them are present in different populations from Europe, Asia, and North America (Arnaiz-Villena et al. 1997, 1999; Clayton and Lonjou 1997; Imanishi et al. 1992; Leffell et al. 2002; Martinez-Laso et al. 1995, 2001; Muro et al. 2001; Sanchez-Velasco et al. 2003). It is remarkable that about half of the first 10 extended $H L A$ haplotypes have been observed only among the Aleuts and are absent in other worldwide populations (Moscoso et al. 2008).

\section{Discussion}

The Aleut $H L A$ alleles described in this study have been used for computer calculations and two-dimensional genetic distances (Moscoso et al. 2008), neighbor-joining trees, correspondence analysis, and the generation of extended HLA haplotypes (see Table 1). The results indicate that on the basis of the HLA system, Aleuts are most closely related to the Saami (Lapps)/Finns and Buryats as well as to other Europeans. By using both allele frequencies and gene genealogy HLA studies (Arnaiz-Villena et al. 2010), we see that Aleut origins are more complicated than previously thought (Greenberg et al. 1986).

Mitochondrial DNA analysis indicates that Aleuts' mtDNA frequent haplogroups have been in existence at least since the 7th century BC (Hayes 2002; Rubicz et al. 2003; Zlojutro et al. 2006). On the other hand, HVS-I sequences show that Aleuts are closer to Asian Siberians (Chukchi, Siberian Eskimos) than to any other American population (Rubicz et al. 2003). The mtDNA variability observed for Bering Island and two Pribilof communities is likely the result of a founder effect, as all three represent aggregate populations that were originally established in the 18th and 19th centuries by Aleut individuals and families forcibly taken from Unalaska and the western Aleutian islands of Attu and Atka to work in the Russian fur trade industry (Zlojutro et al. 2009). Also, Native American gene flow into the eastern Aleut region has come from Yupik and Athabascans from Alaska (Zlojutro et al. 2009).

More detailed and recent studies suggest that Aleut Y-chromosome markers most probably came from Russians in the western and central islands and Western Europeans, including Scandinavians, in the eastern regions and Alaska Peninsula (Zlojutro et al. 2009). It is likely that after the sale of the Alaska territory to the United States in 1867, an influx of fishermen and fur traders of Scandinavian and Western European descent immigrated to the region. As a result of this demographic shift, Aleut-European admixture became commonplace, and non-Native men married Alaskan Aleut women. The genetic impact of Russian colonization and the American purchase of Alaska on the Aleut population is apparent today with only $15 \%$ of the contemporary Y chromosomes being of Native origin.

The relatively large variety of $H L A$ extended haplotypes (Table 1) that are found only in Aleuts and not in other worldwide populations suggests that $H L A$ haplotypes appear more rapidly than $H L A$ alleles in highly admixed, isolated 
populations (Arnaiz-Villena et al. 2010). Indeed, if the first 16 Aleut HLA extended haplotypes are counted, 11 are found only in Aleuts (Moscoso et al. 2008). Neighbor-joining and correspondence analyses relate Aleuts more to Eurasians than to Amerindians. Thus our HLA results are concordant with the Russian and European influx into the Aleut gene pool, as demonstrated in recent times by Ychromosome markers (Zlojutro et al. 2009).

Acknowledgments This work was supported in part by the Spanish Ministry of Health (grants FISS PI051039 and PI080838), the Spanish Ministry of Foreign Affairs (grants A/9134/07 and A/17727/08), and Mutua Madrileña Automovilística (three grants). The collection and extraction of DNA samples from Bering Island was sponsored by the National Science Foundation through grant OPP-9905090 awarded to Michael Crawford.

Received 13 May 2010; accepted for publication 29 June 2010.

\section{Literature Cited}

Arnaiz-Villena, A., P. Iliakis, M. Gonzalez-Hevilla et al. 1999. The origin of Cretan populations as determined by characterization of HLA alleles. Tissue Antigens 53:213-226.

Arnaiz-Villena, A., J. Martinez-Laso, E. Gomez-Casado et al. 1997. Relatedness among Basques, Portuguese, Spaniards, and Algerians studied by HLA allelic frequencies and haplotypes. Immunogenetics 47:37-43.

Arnaiz-Villena, A., C. Parga-Lozano, E. Moreno et al. 2010. The origin of Amerindians and the peopling of the Americas according to HLA genes: Admixture with Asian and Pacific people. Curr. Genom. 11:104-113.

Clayton, J., and C. Lonjou. 1997. Allele and haplotype frequencies for HLA loci in various ethnic groups. In Genetic Diversity of HLA: Functional and Medical Implications, D. Charron, ed. Paris: EDK, 665-820.

Crawford, M. H. 2007. Genetic structure of circumpolar populations: A synthesis. Am. J. Hum. Biol. 19:203-217.

Greenberg, J. H., C. G. Turner, and S. L. Zegura. 1986. The settlement of the Americas: A comparison of the linguistic, dental, and genetic evidence. Curr. Anthropol. 27:477-498.

Hayes, M. G. 2002. Paleogenetic Assessments of Human Migration and Population Replacement in North America History. Ph.D. dissertation, University of Utah.

Imanishi, T., T. Akaza, A. Kimura et al. 1992. Allele and haplotype frequencies for HLA and complement loci in various ethnic groups. In HLA 1991, K. Tsuji, M. Aizawa, and T. Sasazuki, eds. Oxford, U.K.: Oxford University Press, 1065-1220.

Leffell, M. S., M. D. Fallin, H. A. Erlich et al. 2002. HLA antigens, alleles, and haplotypes among the Yup'ik Alaska natives: Report of the ASHI Minority Workshops, Part Il. Hum. Immunol. 63:614-625.

Martinez-Laso, J., D. de Juan, N. Martinez-Quiles et al. 1995. The contribution of the HLA-A, -B, $-C,-D R$, and $-D Q$ DNA typing to the study of the origins of Spaniards and Basques. Tissue Antigens 45:237-245.

Martinez-Laso, J., M. Sartakova, L. Allende et al. 2001. HLA molecular markers in Tuvinians: A population with both Oriental and Caucasoid characteristics. Ann. Hum. Genet. 65:245-261.

Moscoso, J., M. H. Crawford, J. L. Vicario et al. 2008. HLA genes of Aleutian islanders living between Alaska (USA) and Kamchatka (Russia) suggest a possible southern Siberia origin. Mol. Immunol. 45:1018-1026. 


\section{4 / REY ET AL.}

Muro, M., L. Marin, A. Torio et al. 2001. HLA polymorphism in the Murcia population (Spain): In the cradle of the archaeologic Iberians. Hum. Immunol, 62:910-921.

Rubicz, R., T. G. Schurr, P. L. Babb et al. 2003. Mitochondrial DNA variation and the origins of the Aleuts. Hum. Biol. 75:809-835.

Sanchez-Velasco, P., E. Gomez-Casado, J. Martinez-Laso et al. 2003. HLA alleles in isolated populations from north Spain: Origin of the Basques and the ancient Iberians. Tissue Antigens 61:384-392.

Zlojutro, M., R. Rubicz, and M. H. Crawford. 2009. Mitochondrial DNA and Y-chromosome variation in five eastern Aleuts communities: Evidence for genetic substructure in the Aleut population. Ann. Hum. Biol. 36:51 1-526.

Zlojutro, M., R. Rubicz, E. J. Devor et al. 2006. Genetic structure of the Aleuts and circumpolar populations based on mitochondrial DNA sequences: A synthesis. Am. J. Phys. Anthropol. 129:446-464. 